\title{
Complete and Early Vitrectomy for Endophthalmitis [Letter]
}

\author{
Surbhi Agrawal (D) \\ Sankara Eye Hospital, Bangalore, India
}

Correspondence: Surbhi Agrawal

Sankara Eye Hospital, Varthur Road,

Kundalhalli Junction, Bangalore, 560037, India

Tel +919702023675

Email dr.agrawalsurbhi@gmail.com

\section{Dear editor}

I read with great interest the article on Complete and Early Vitrectomy by Dib et al. ${ }^{1}$ The article heralds a paradigm shift from the recommendations of the landmark EVS trial. ${ }^{2}$ The principles and theory discussed in the article seem to be guided by sound scientific principles. However, a few practical considerations came to the mind while reading the article, and I would like to raise these points here.

The authors suggest that the rates of retinal detachment may not be increased by modern high-speed vitrectors. This statement could have been backed up by data from their study. While the overall rates of RD in the study have been quoted to be $6.4 \%$, individual rates for the vitrectomy and intravitreal group have not been quoted. It would also be interesting to note if any eyes developed a retinal tear intraoperatively and if this was associated with PVD induction.

All the patients in the study under consideration received systemic vancomycin or moxifloxacin. These drugs are known to have better penetration of the bloodocular barrier compared to the drugs used in the EVS study. This is a significant factor and may have greatly contributed to the better visual outcomes of the current study. Additionally, as the authors have acknowledged, the retreatment rates of their study were much higher than the EVS group. Re-treatment may have a greater impact on visual outcomes than the initial choice of treatment. Repeated intravitreal injections may avert the need for multiple vitreo-retinal surgeries and the associated financial and emotional strain.

Several factors including severity of retinopathy, initial culture results and media clarity have been noted to influence retreatment decisions in the study. However, how exactly these factors influenced decision-making has not been elucidated. If the principles of this study were to be adopted into practice, knowledge of how these factors influenced retreatment would be crucial. Media opacity has been quoted to be one of the main factors influencing the decision to treat. However, the objective or subjective methods used to grade the media opacity have not been clarified. In this regard, a question also arises as to whether the twice daily examinations for each patient were all performed by the same examiner. If not, then the matter of employing a repeatable media opacity grading becomes even more pertinent.

The authors have statistically compared the outcomes of their study with the outcomes of the EVS and found the difference to be significant. A statistical comparison of the baseline data of both studies would have further validated the outcome analysis. 


\section{Disclosure}

The author reports no conflicts of interest in this communication.

\section{References}

1. Dib B, Morris RE, Oltmanns MH, et al. Complete and early vitrectomy for endophthalmitis after cataract surgery: an alternative treatment paradigm. Clin Ophthalmol. 2020;14:1945-1954. doi:10.2147/ OPTH.S253228
2. [No authors listed]. Results of the Endophthalmitis Vitrectomy Study: a randomized trial of immediate vitrectomy and of intravenous antibiotics for the treatment of postoperative bacterial endophthalmitis. Arch Ophthalmol. 1995;113(12):1479-1496. doi:10.1001/ archopht.1995.01100120009001

Dove Medical Press encourages responsible, free and frank academic debate. The content of the Clinical Ophthalmology 'letters to the editor' section does not necessarily represent the views of Dove Medical Press, its officers, agents, employees, related entities or the Clinical Ophthalmology editors. While all reasonable steps have been taken to confirm the content of each letter, Dove Medical Press accepts no liability in respect of the content of any letter, nor is it responsible for the content and accuracy of any letter to the editor

\section{Publish your work in this journal}

Clinical Ophthalmology is an international, peer-reviewed journal covering all subspecialties within ophthalmology. Key topics include: Optometry; Visual science; Pharmacology and drug therapy in eye diseases; Basic Sciences; Primary and Secondary eye care; Patient Safety and Quality of Care Improvements. This journal is indexed on PubMed

Submit your manuscript here: https://www.dovepress.com/clinical-ophthalmology-journal
Central and CAS, and is the official journal of The Society of Clinical Ophthalmology (SCO). The manuscript management system is completely online and includes a very quick and fair peer-review system, which is all easy to use. Visit http://www.dovepress.com/ testimonials.php to read real quotes from published authors. 